\title{
Exploring Tourists' Environmental Learning, Values, and Travel Experiences in Re- lation to Climate Change: A Postmodern Constructivist Research Agenda
}

\begin{abstract}
There is a need for a research agenda, which achieves a holistic understanding of the nature and influences of environmental learning on tourists' environmental values and travel experiences in relation to climate change. Why, because tourists' environmental values and environmentally friendly behaviour have been the focus of predominantly quantitative studies within the ecotourism context. Such studies generally neglect influences over time and the multiple and diverse nature of tourists' environmental learning experiences along with their social reconstruction. The suggested agenda is predicated on a review of extant literature related to tourists' environmental values, environmental learning, and travel experiences. The agenda identifies aims, potential research questions and advocates a postmodern constructivist research paradigm to inform the research agenda. By advancing this research agenda, the paper contributes towards the goal of the Decade of Education for Sustainable Development.
\end{abstract}

Key Words: Environmental values, environmental learning, free-choice learning, climate change, travel experiences. 


\section{Introduction}

Dialogues about climate change are not new having commenced more than fifty years ago (Keith, 2007). Despite this history of dialogue, climate change remains a critical global issue and is one of the biggest contemporary threats to societies in the world. As a threat, it is yet to be collectively and responsibly addressed on a global scale. Briefly, climate change is caused by increased carbon dioxide emissions; and relatedly, is predicted to cause estimated global temperature rises between 1.4 and $5.8 \mathrm{C}^{\circ}$ (Viner and Nicholls, 2006). Some commentators question the validity of climate change data (Bast, 2009). The Intergovernmental Panel on Climate Change (IPCC), however, is emphatic: climate change is happening and human society contributes to this phenomenon (IPCC, 2007).

The human phenomena of tourism is seen as both a contributor to and a "victim" of climate change (WTO, 2003). Moreover, climate change and tourism are inextricably interlinked to sustainability agendas, which date back to the Brundtland Report (WCED, 1987). If tourism is both a contributor and a victim with regard to climate change, what then is the role of tourists? How are they positioned with regard to climate change and sustainability debates? What knowledge economies do they participate in and why? How do media and social networks facilitate and shape tourists' environmental learning, values and travel experiences? This paper proposes a research agenda framed to address these questions. In particular, the paper advocates the use of a postmodern constructivist lens to study the nature and influences of environmental learning on tourists' environmental values and travel experiences. Why? Because a postmodern constructivist lens adopts an ontology, which does not privilege any particular view of the world: all views are subjectively determined (a relativist epistemology) and equally 'valid' interpretations. 
Methodologies tend towards qualitative methods and carry a sceptical axiological position associated with continuous deconstruction processes (Jennings, 2009).

\section{Paper overview}

The paper commences with a contextualisation of tourism planning agendas, particularly movement from boosterism to sustainability platforms. It then moves on to consider tourists' environmental values and identifies that most research about environmental values has been predicated on the use of quantitative research. Environmental learning is discussed, especially the impact of free-choice learning and influences on tourists' values. In relation to learning, it is noteworthy that 2005-2014 is the Decade of Education for Sustainable Development (UNESCO, n.d.). This paper and its associated research agenda support the goal of this decade. Following the discussion of environmental learning, the paper considers the multiplicities and complexities of travel experiences. The paper then proffers a research agenda for the study of the nature and influences of environmental learning on tourists' environmental values and travel experiences in relation to climate change. This agenda emphasises the use of grounded theory as an appropriate methodological framework for such a research agenda. The informing paradigm necessitates the use of a narrative, first person active voice (Jennings, 2010). Subsequently, readers will see and hear our presence in the paper's text. Further, the paper adopts the use of question - reflection format (Yin, 2009) due to the reflexive processes (Hertz, 1997; Jennings, 2010), in which we engaged in the course of writing this paper.

\section{Background}

Over time in developed nations, the earlier tourism planning traditions of 1950 s and 1960s, specifically, boosterism and economic traditions were countered in the 1970s by 
physical/spatial and community oriented planning traditions (Getz, 1986, 1987). Relatedly, in the 1980s, Our Common Future (the Brundtland Report) defined sustainable development as "development that meets the needs of the present without compromising the ability of future generations to meet their own needs" (WCED, 1987). The Rio Summit, Agenda 21, reaffirmed the principles of the Brundtland Report. More recently, the United Nations Educational Scientific and Cultural Organization (UNESCO) declared the 20052014, the Decade of Education for Sustainable Development. This paper specifically contributes to UNESCO's goal for the decade 2005-2014, which “is to integrate the principles, values, and practices of sustainable development into all aspects of education and learning” (UNESCO, n.d.). In particular, the paper contributes to generating knowledge about free-choice learning engagements and the consequences of such engagements for values, sustainability and tourist travel experience decision-making with regard to climate change imperatives. It must be noted, however, that the designation of this decade along with the primarily developed world "mainstream” interpretations regarding the interpretation of sustainability are only just beginning to align with a number of long-held indigenous peoples' concepts of stewardship of the land, resources and interconnectivity of all things (Jennings, 2007b).

With regard to tourism, concomitantly, in the 1980s, as sustainability agendas were entering global discourses the development of environmentally friendly tourism concepts, such as ecotourism, emerged and resonated with sustainable development and sustainability platforms. These platforms were and still are cognizant of human caused impact on the environment, biodiversity, and its conservation. The pursuit of such platforms essayed to have negligible impact on the environment and resultantly on climate. While a number of tourism studies have investigated tourists' motivations and behaviours regarding more en- 
vironmentally friendly types of tourism (Dolnicar, 2004; Higham, 2007; Higham and Carr, 2002; Kim et al, 2006; Zografos and Allcroft, 2007), little is known about how climate change influences tourists' values and their decisions towards more environmentally friendly tourism experiences. Moreover, only a few studies focus on tourists and their perceptions of climate change in the tourism context (Becken, 2004, 2007; Gössling et al, 2006; Kachel and Jennings, 2009). Becken’s (2004) study revealed that tourists question links between climate change and tourism. A more recent qualitative inquiry emphasised the importance of information and knowledge on environmental issues, which could lead to pro-environmental attitudes (Becken, 2007). Kachel and Jennings’ (2009) analysis of existing online discussions of climate change within an online travel community revealed that tourists can be grouped into believers, undecideds, and non-believers regarding the existence of climate change.

Subsequently, tourists' knowledge and perceptions of climate change as well as the learning processes involved, need to be placed on tourism research agendas. Such agendas should also incorporate questions related to what are tourists' climate change information needs, how have tourists' obtained environmental knowledge and information, and how do environmental learning experiences influence tourists' environmental values and tourism experiences.

\section{Tourists’ Environmental Values}

Tourists' environmental motivation and behaviour may partially be contextualised within the ecotourism concept. The International Ecotourism Society (TIES), a contributor in promoting sustainable tourism, defines ecotourism as "responsible travel to natural areas that conserves the environment and improves the well-being of local people" (TIES, 
2007). Reports on actual growth rates in ecotourism, however, are inconsistent throughout the tourism industry and it is questionable that such growth is consumer driven (Sharpley, 2006). This view contradicts TIES's definition of ecotourism, which implies tourists' consciousness links to responsible travel. Due to limited empirical evidence, Sharpley is not alone in his critique. The existence of an environmentally aware tourist demanding environmentally friendly tourism products is also questioned by Swarbrooke and Horner (Swarbrooke and Horner, 2007). These authors define and recognise the ecotourist as a 'green tourist' who belongs to different 'shades of green tourists' regarding her or his individual environmental values and motivations. These shades from light to dark green are characterised through their environmental awareness, knowledge and attitudes, as well as their personal, family and work lives. Further, Swarbrooke and Horner (2007), as well as Sharpley (2006), identified an increased interest by tourists in green tourism or ecotourism products, though, this interest does not appear to be shaped by increased motivations related to environmental sustainability. Other studies associated with environmental values are presented in overview in Table 1. Of particular note in this table, are the numbers of studies that have been undertaken using a quantitative perspective. Qualitative research is under-represented and under-utilized.

Table 1: Examples of environmental values studies (Kachel, 2008)

\begin{tabular}{lll}
\hline Authors & Study focus & Methodology \\
\hline Dunlap, Van Liere & Development and testing of the New Envi- & Quantitative \\
and Mertig (2000) & $\begin{array}{l}\text { ronmental Paradigm (NEP), which lists 15 } \\
\text { statements regarding a general ecological }\end{array}$ & \\
& worldview & \\
Higham and Carr & Explored environmental values of ecotourists & Qualitative \\
(2002) & & \\
\hline
\end{tabular}




\begin{tabular}{lll}
\hline Lück (2003) & $\begin{array}{l}\text { Investigated the influence of education on } \\
\text { wildlife conservation }\end{array}$ & Quantitative \\
Dolnicar (2004) & $\begin{array}{l}\text { Used a single-item measure and demographic } \\
\text { data to define sustainable and non-sustainable } \\
\text { tourists }\end{array}$ & Quantitative \\
& Used the NEP to measure impacts of environ- & Quantitative \\
Kim, Borges and & mental values on tourism motivation & \\
Chon (2006) & Used the NEP to segment ecotourists & Quantitative \\
Zografos and Allcroft & & \\
(2007) & Investigated attitudes, opinion and behaviours & Quantitative \\
Singh, Slotkin and & of ecotourists visiting an event & \\
Vamosi (2007) &
\end{tabular}

As noted in Table 1, in order to understand tourists' environmental motivations and behaviours, market segmentation and the New Environmental Paradigm (NEP) (Dunlap et al, 2000), have both been used to define tourists' environmental values. One factor that influences environmental values is environmental information received during tourism experiences. This factor highlights that values can and do change over time (Higham and Carr, 2002; Lück, 2003; Singh et al, 2007; Swarbrooke and Horner, 2007).

This review of tourists' environmental values contributes to refining this paper's proposed research agenda. Especially, questions that need to be framed, which further understandings of how knowledge and information on environmental issues like climate change influence tourists' environmental values, for example, in what contexts and why? Such questions include how do knowledge and information on environmental issues related to climate change influence tourists' environmental values and why? Which media are the most effective for eliciting change and why? In what contexts are knowledge and information regarding environmental values associated with climate change most influential in tourists' experiences and why? Table 1 demonstrates the dominant approach for measur- 
ing tourists' environmental values with predefined environmental statements is a quantitative one. These methods, however, are inappropriate for holistically understanding how tourists' environmental values are shaped and linked to their chosen travel experience. They also fall short of understanding "how" and "why”. Jamal and Hollinshead, (2001) and Jennings (2007a) argue that qualitative research is an effective means to achieve such understandings. Hence, this paper proposes the use of qualitative research in relation to its proposed research agenda. In particular, as already mentioned, the paper advocates a postmodern constructivist approach, which acknowledges a multiplicity of values and experiences, which are socially constructed and continuously change over time.

\section{Environmental Learning}

As the Decade of Education for Sustainable Development promotes, learning is a crucial element towards achieving a more sustainable future as it has the ability to promote change (Scott and Gough, 2003; Sterling, 2007). It is recognised, however, that knowledge about environmental values or attitudes does not necessarily lead to a positive change. This is an under-researched area, as Rickinson (2006) notes, learning processes and outcomes of environmental education are not yet well researched and understood, and emphasis still focusses on outcomes rather than the processes (Falk, 2005; Rickinson, 2001).

For the purpose of this paper, environmental learning has been defined as engagement with the environment or environmental thinking (Scott and Gough, 2003). Falk (2005) states the majority of environmental learning, and learning in general, happens outside formal education settings. But what is learning? Learning is a cumulative, combined process of knowledge acquisition and construction within social and cultural contexts (Falk, 2005). If, however, such processes and contexts have been chosen and controlled by learn- 
ers then free-choice learning, a form of informal learning, occurs (Falk, 2005; Falk and Dierking, 2000). Studies in Table 2 address such informal learning processes in tourismrelated settings.

Table 2: Studies on free-choice learning in tourism-related settings (Kachel, 2008)

\begin{tabular}{ll}
\hline Study areas & Authors \\
\hline Museums and exhibitions & Falk and Dierking (2000) \\
Packer and Ballantyne (2002) & Storksdieck, Ellenbogen, and Heimlich (2005) \\
National parks/ natural areas & Brody and Tomkiewicz (2002) \\
& Boyer and Roth (2005) \\
& Ballantyne, Packer, and Hughes (2008) \\
& Packer \& Ballantyne (2002) \\
Zoos and aquariums & Torfield, Coll, Vyle, and Bolstad (2003) \\
& Ballantyne, Packer, Hughes, and Dierking (2007) \\
& Randler, Baumgärtner, Eisele, and Kienzle (2007) \\
& Ballantyne, Packer, Hughes, and Dierking (2007) \\
& Zeppel (2008) \\
\hline
\end{tabular}

As stressed by several authors (Brody and Tomkiewicz, 2002; Falk, 2005; Rickinson, 2006), the important question is - how do people learn? Brody and Tomkiewicz (2002) state that past experiences and knowledge, the actual learning experience; as well as communication and sharing with others, have a huge influence on what people learn. Of potential relevance may also be Gibbons' (1994; Nowotny et al, 2001) modes of knowledge, based on a knowledge production which is transformed into a social activity and emphasises the role of life-long learning. 
In free-choice learning, the underlying motivations and interests of learners are key drivers (Falk, 2005). Free-choice environmental learning, for example, occurs while watching a documentary on TV, reading a book or magazine, participating in a community-based or environmental organisation, or searching the Internet (Falk, 2005). In the ecotourism context, learning about the environment is seen as an important part of the tourism experience and usually received through interpretation (Higham and Carr, 2002; Kimmel, 1999; Lück, 2003; Price, 2004; Swarbrooke and Horner, 2007).

Subsequently, research that explores and explains how tourists acquire their environmental knowledge will further an understanding of influences on tourists' environmental values and serve to support sustainability and climate change agendas. In addition to the following question, questions posed in the preceding section have overlap with this section. Bearing in mind the content of this section, we also need to ask: do tourists engage in environmental free-choice learning about climate change during their travel experiences? If so, why and how; if not, why not? Falk (2005) defines learning as a cumulative, combined process of knowledge acquisition and construction within social and cultural contexts. As a consequence, a postmodern constructivist paradigm provides a complementary socially based process for understanding tourists’ learning processes.

\section{Travel experiences}

While some extant literature essays to universally define what a travel or tourist experience is (Jennings, 2006), such essays are problematic. As other extant literature acknowledges meanings are multiple, constantly changing and reinterpreted (Ryan, 2002). Given this diversity in perspectives, in using the term travel or tourist experience, the authors are 
referring to an individual's experience while engaging with travel and tourism activities. As the travel experience is a very personal and individual construct, one can only gain an understanding of what a travel experience represents for a tourist when interacting directly with the person (Jennings and Weiler, 2006).

Literature on tourist or travel experiences is extensive, and more recently postmodern views and discourses have contributed to dialogues about the tourist experience (Jennings, 2006; Uriely, 2005). This postmodern shift (Table 3) comprehends travel experiences as diverse, subjective, and part of everyday life experiences.

Table 3: Conceptual developments of the nature of tourists' experiences (Uriely, 2005)

- Reconsideration of the distinctiveness of tourism from everyday life's experiences

- Shift from homogenizing portrayals of the tourist as general type to pluralizing depictions that capture the multiplicity of the experience

- Shifted focus from the displayed objects provided by the industry to the subjective negotiation of meanings as a determinant of the experience

- Movement from contradictory and decisive academic discourse, which conceptualises the experience in terms of absolute truths, toward relative and complementary interpretations

Similarly, in other extant literature there is recognition of the multiple, multi-modal/phase and sometimes nebulous and particularised nature of travel experiences as well as the inclusion of travel experiences in everyday life (see Table 4).

Table 4: Relevant concepts of travel experiences (Kachel, 2008)

\begin{tabular}{lll}
\hline Author(s) & Focus & Pertinence \\
\hline Urry (2002) & Multiplicity of the tourist experience & Continue at home while sharing \\
Lash and & Holidays and everyday lives are blur- & travel experiences online
\end{tabular}


ring

Urry People are being tourists all the time

Ryan Inclusion of recreation and leisure in Part of everyday life's activities

(2002) everyday or work lives

Killion Circular model (Clawson, 1963) of Reflections are made on pre, during,

different travel phases:

and post travel experiences

Planning, travel to, on-site activities,

return travel, and recollection

Given the preceding, further questions are generated for our proposed research agenda. How do multiple travel experiences influence tourists' environmental values in relation to climate change and why? How does the inclusion of travel experiences in everyday life's activities influence tourists' environmental values in relation to climate change and why? How do the differing stages of experiences influence tourists' environmental values in relation to climate change and why? How do environmental values in relation to climate change impact on tourists' travel experiences and why? Is environmental learning about climate change part of tourists' travel experiences? If so, why; if not, why not? These questions focus on how and why. A focus from which adopts a postmodern constructivist approach provides a suitable lens to gain insight and understanding.

\section{Research agenda: Recommended informing paradigm}

The extant literature demonstrates a paucity of qualitatively informed research. Qualitative research enables researchers to gain insights into the "how” and the "why” (see Jennings, 2010) of the nature and influences of environmental learning on tourists' environmental values and travel experiences in relation to climate change. Subsequently, this paper continually advances a postmodern constructivist lens as appropriate to achieve holistic per- 
spectives of the "how" and "why", in order to gain understandings of the complex and multiple nature of values, environmental learning, travel experiences, sustainability, and climate change.

A postmodern constructivist lens adopts an ontology, which does not privilege any particular view of the world: all views are subjectively determined (a relativist epistemology) and equally 'valid' interpretations. Methodologies tend towards qualitative methods and carry a sceptical axiological position associated with continuous deconstruction processes. Given the diversity in and perspectives of travellers, it is fitting to use such a paradigm as a lens to understand the nature and influences of environmental learning on tourists' environmental values and travel experiences in relation to climate change.

Within the qualitative research fields, we promote a grounded theory approach for empirical material collection and analysis to address such an agenda. In particular, a grounded theory approach that follows Charmaz (2005, 2006) and Clarke (2005) approaches is recommended. Their approaches define grounded theories as co-constructions of realities from past or present experiences or interactions and, for this research agenda, enable multiple deconstructions and reconstruction. In adopting a grounded theory approach, theoretical frameworks, constructs and theories are able to be identified and/or articulated. Identification of these occurs in the process of the development of the grounded theory itself (Jennings and Junek, 2007). It is our perspective that use of grounded theory enables the nature and influences of environmental learning on tourists' environmental values and travel experiences in relation to climate change to be generated from within the processes and experiences of the travellers both holistically and in situ. We acknowledge that the 
theoretical processes that arise will be multiple in nature to accord with the principles of not privileging one position over another.

\section{Research Agenda: Aims and Questions}

The paper has posed a number of questions, which arose from review of literature and extant knowledge of tourists' environmental learning, values, travel experiences and climate change. On several occasions the paper has made reference to a proposed research agenda. The research agenda is focussed on studying the nature and influences of environmental learning on tourists' environmental values and travel experiences. The paper now turns its attention to the presentation of that agenda. The agenda is constituted of two parts. The first presents the aims and the second, potential questions that may arise or be used in the course of empirical material collection.

The research agenda aims are to:

- Investigate what influences tourists' environmental values in relation to climate change;

- Understand the relation between environmental values and environmental learning;

- Explore how environmental awareness, knowledge, and attitudes influence environmental values;

- Understand what factors change tourists' environmental values over time;

- Investigate tourists' involvement in environmental learning in relation to climate change;

- Investigate the influence of environmental learning on environmental values with respect to climate change; 
- Investigate the influence of environmental learning about climate change on travel experiences;

Key research questions include:

- What are tourists' climate change information needs?

- How do tourists gain environmental knowledge and information about climate change?

- How do knowledge and information on environmental issues related to climate change influence tourists' environmental values and why?

- Which media are the most effective for eliciting change and why?

- In what contexts are knowledge and information regarding environmental values associated with climate change most influential in tourists’ experiences and why?

- What are tourists' environmental values in relation to climate change?

- How do tourists engage in environmental learning experiences in relation to climate change?

- How do environmental learning experiences influence tourists' environmental values and tourism experiences?

- Do tourists engage in environmental free-choice learning about climate change during their travel experiences? If so, why and how; if not, why not?

- In what travel settings do tourists engage in environmental learning about climate change?

- How do multiple travel experiences influence tourists’ environmental values in relation to climate change and why?

- How does the inclusion of travel experiences in everyday life's activities influence tourists' environmental values in relation to climate change and why? 
- How do the differing stages of experiences influence tourists' environmental values in relation to climate change and why?

- How do environmental values in relation to climate change impact on tourists' travel experiences and why?

- Is environmental learning about climate change part of travel experiences? If yes, why; if not, why not?

The outcome of such an agenda will be research that explores and explains how tourists acquire their environmental knowledge about climate change. This will further understandings of influences on tourists' environmental values and serve to support related sustainability and climate change research agendas. To reiterate, to complement this agenda's focus on 'how' and 'why', postmodern constructivism and grounded theory approaches are suggested as suitable research lenses. These lenses enable the study of the coconstruction and deconstruction of environmental learning experiences, whilst acknowledging and including multiple perspectives. They further allow theory to be reconstructed from within study contexts and environments themselves.

\section{Conclusion}

To date, in related literature, only a few studies focus on tourists and their perceptions of climate change in the tourism context (Becken, 2004, 2007; Gössling et al, 2006; Kachel and Jennings, 2009). The majority of studies on tourists’ perceptions have used a quantitative approach, with Becken's (2007) and Kachel and Jennings' (2009) qualitative inquiry promising a deeper insight into tourists' perceptions. These studies, however, do not relate tourists' perceptions or knowledge on climate change to their environmental values and travel experiences. 
To address identified "gaps in knowledge” regarding studying the nature and influences of environmental learning on tourists' environmental values and travel experiences in relation to climate change, this paper has provided tourism and travel researchers with a research agenda. That agenda is constituted of aims and potential research questions, a recommended paradigm, that is, a postmodern constructivist lens, along with a grounded theory orientation towards knowledge and “theory” development. Our agenda contributes to stimulating future research studies and projects that focus on the inter-play of values, learning, tourist travel experiences and sustainability, with particular regard to climate change imperatives.

In advancing this agenda, we are mindful that it is but one of many agendas that may be constructed. It is our hope that in reading this paper readers will engage in their own reflexive processes and subsequently reconstruct our agenda as well as construct their own. Our paradigmatic perspective recognises that perspectives are multiple. Such multiplicity only serves to advance further dialogue and research with regard to achieving holistic understandings of the nature and influences of environmental learning on tourists' environmental values and travel experiences in relation to climate change. 


\section{References}

Ballantyne, R., Packer, J. and Hughes, K. (2008) Environmental awareness, interests and motives of botanic gardens visitors: Implications for interpretive practice. Tourism Management 29(3): 439-444.

Ballantyne, R., Packer, J., Hughes, K. and Dierking, L.D. (2007) Conservation learning in wildlife tourism settings: Lessons from research in zoos and aquariums. Environmental Education Research 13(3): 367-383.

Bast, J.L. (2009) Putting an End to Global Warming Alarmism. Heartland Perspectives, http://www.heartland.org/full/24456/Putting_an_End_to_Global_Warming_Alarmism.htm l, accessed 8 January.

Becken, S. (2004) How tourists and tourism experts perceive climate change and carbonoffsetting schemes. Journal of Sustainable Tourism 12(4): 332-345.

Becken, S. (2007) Tourists' perception of international air travel's impact on the global climate and potential climate change policies. Journal of Sustainable Tourism 15(4): 352368.

Boyer, L. and Roth, W.-M. (2005) Individual | collective dialect of free-choice learning in a community-based mapping project. Environmental Education Research 11(3): 335-351.

Brody, M. and Tomkiewicz, W. (2002) Park visitors' understandings, values and beliefs related to their experience at Midway Geyser Basin, Yellowstone National Park, USA. International Journal of Science Education 24(11): 1119-1141.

Charmaz, K. (2005) Grounded theory in the 21st century: Applications for advancing social justice studies. In: N.K. Denzin and Y.S. Lincoln (eds.) The Sage handbook of qualitative research. 3rd Edition. Thousand Oaks, Calif.: Sage Publications. 
Charmaz, K. (2006) Constructing grounded theory: A practical guide through qualitative analysis London; Thousand Oaks: SAGE.

Clarke, A.E. (2005) Situational analysis: Grounded theory after the postmodern turn Thousand Oaks: SAGE Publications.

Clawson, M. (1963) Land and water for recreation: Opportunities, problems and policies Chicago: Rand McNally.

Dolnicar, S. (2004) Insights into sustainable tourism in Austria: A data-based a priori segmentation approach. Journal of Sustainable Tourism 12(3): 209-218.

Dunlap, R.E., Van Liere, K.D., Mertig, A.G. and Jones, R.E. (2000) Measuring endorsement of the new environmental paradigm: A revised NEP scale. Journal of Social Issues 56(3): 425-442.

Falk, J.H. (2005) Free-choice environmental learning: Framing the discussion. Environmental Education Research 11(3): 265-280.

Falk, J.H. and Dierking, L.D. (2000) Learning from museums: Visitor experiences and the making of meaning. American Association for State and Local History book series. Walnut Creek, CA: AltaMira Press.

Getz, D. (1986) Models of tourism planning towards integration of theory and practice. Tourism Management 7(1): 21-32.

Getz, D. (1987) Tourism planning and research: Traditions, models and futures. Proceedings of the The Australian Travel Research Workshop; November 5-6, Bunbury, Western Australia. 
Gibbons, M. (1994) The new production of knowledge: The dynamics of science and research in contemporary societies London: Sage.

Gössling, S., Bredberg, M., Randow, A., Sandström, E. and Stevensson, P. (2006) Tourist perceptions of climate change: A study of international tourists in Zanzibar. Current Issues in Tourism 9(4\&5): 419-435.

Hertz, R. ed. (1997) Reflexivity \& voice. Thousand Oaks: SAGE Publications.

Higham, J.E.S. (2007) Critical issues in ecotourism: Understanding a complex tourism phenomenon Amsterdam: Elsevier, Butterworth Heinemann.

Higham, J.E.S. and Carr, A. (2002) Ecotourism visitor experiences in Aotearoa/New Zealand: Challenging the environmental values of vistors in pursuit of por-environmental behaviours. Journal of Sustainable Tourism 10(4): 277-294.

IPCC. (2007) Climate change 2007: The physical science basis. Summary for policymakers. Paris: Intergovernmental Panel on Climate Change.

Jamal, T.B. and Hollinshead, K. (2001) Tourism and the forbidden zone: The underserved power of qualitative inquiry. Tourism Management 22: 63-82.

Jennings, G.R. (2006) Perspectives on quality tourism experiences: An introduction. In: G.R. Jennings and N.P. Nickerson (eds.) Quality tourism experiences. Burlington, MA: Elsevier Butterworth-Heinemann.

Jennings, G.R. (2007a) Advances in tourism research: Theoretical paradigms and accountability. In: A. Matias, P. Nijkamp and P. Neto (eds.) Advances in modern tourism research: Economic perspectives. Heidelberg: Physia-Verlag. 
Jennings, G.R. (2007b) Sustainability of tourism: Sport, adventure and recreation in water based environments. In: G. Jennings (ed.) Water-based tourism, sport, leisure and recreation. London: Elsevier.

Jennings, G.R. (2010) Tourism research. 2nd Edition Milton, Australia: John Wiley \& Sons.

Jennings, G.R. and Junek, O. (2007) Grounded theory: Innovative methodology or a critical turning from hegemonic methodological praxis in tourism studies? In: I. Ateljevic, A. Pritchard and N. Morgan (eds.) The critical turn in tourism studies: Innovative research methodologies. Oxford, UK: Elsevier Science.

Jennings, G.R. and Weiler, B. (2006) Mediating meaning: Perspectives on brokering quality tourism experiences. In: G.R. Jennings and N.P. Nickerson (eds.) Quality tourism experiences. Burlington, MA: Elsevier Butterworth-Heinemann.

Kachel, U. (2008) A grounded theory of tourists' online discussion of climate change and influences on travel experiences. Unpublished Confirmation Paper. Griffith University.

Kachel, U. and Jennings, G. (2009) Believe it or not: Travellers' perspectives on climate change and connectivity to travel decision-making - A constructivist interpretation. In: J. Carlsen, M. Hughes, K. Holmes and R. Jones (eds.). Proceedings of the Proceedings of the 18th CAUTHE Conference; 10-13 February, Perth. Perth: Promaco Conventions.

Keith, D. (2007) A surprising idea for "solving" climate change. In: TED Talks, (ed.) TED. Long Beach, USA: TED.

Killion, G.L. (1992) Understanding tourism. Unpublished Study Guide. Central Queensland University.

Kim, H., Borges, M.C. and Chon, J. (2006) Impacts of environmental values on tourism motivation: The case of FICA, Brazil. Tourism Management 27: 957-967. 
Kimmel, J.R. (1999) Ecotourism as environmental learning. The Journal of Environmental Education 30(2): 40-44.

Lash, S. and Urry, J. (1994) Economies of signs and space. Theory, culture \& society. London: Sage.

Lück, M. (2003) Education on marine mammal tours as agent for conservation - but do tourists want to be educated? Ocean \& Coastal management 46: 943-956.

Nowotny, H., Scott, P. and Gibbons, M. (2001) Re-thinking science: Knowledge and the public in an age of uncertainty Cambridge, England: Polity.

Packer, J. and Ballantyne, R. (2002) Motivational factors and the visitor experience: A comparison of three sites. Curator 45(3): 183-198.

Price, G.G. (2004) Ecotourism operators and environmental education: Enhancing competitive advantage by advertising environmental learning experiences. Tourism Analysis 8: $143-147$.

Randler, C., Baumgärtner, S., Eisele, H. and Kienzle, W. (2007) Learning at workstations in the zoo: A controlled evaluation of cognitive and affective outcomes. Visitor Studies 10(2): 205-216.

Rickinson, M. (2001) Learners and learning in environmental education: A critical review on the evidence. Environmental Education Research 7(3): 207-320.

Rickinson, M. (2006) Researching and understanding environmental learning: Hopes for the next 10 years. Environmental Education Research 12(3-4): 445-457.

Ryan, C. ed. (2002) The tourist experience. 2nd Edition. London, New York: Continuum. 
Scott, W. and Gough, S. (2003) Sustainable development and learning: Framing the issues London ; New York: RoutledgeFalmer.

Sharpley, R. (2006) Ecotourism: A consumption perspective. Journal of Ecotourism 5(1\&2): 7-22.

Singh, T., Slotkin, M.H. and Vamosi, A.R. (2007) Attitude towards ecotourism and environmental advocacy: Profiling the dimensions of sustainability. Journal of Vacation Marketing 13: 119-134.

Sterling, S. (2007) Riding the storm: Towards a connective cultural consciousness. In: A.E.J. Wals (ed.) Social learning towards a sustainable world: Principles, perspectives, and praxis. Netherlands: Wageningen Academic Publishers

Storksdieck, M., Ellenbogen, K. and Heimlich, J.E. (2005) Changing minds? Reassessing outcomes in free-choice environmental education. Environmental Education Research 11(3): 353-369.

Swarbrooke, J. and Horner, S. (2007) Consumer behaviour in tourism. 2nd Edition London; Burlington, MA: Butterworth-Heinemann.

TIES. (2007) The International Ecotourism Society Website, http://www.ecotourism.org/, accessed 3 April.

Tofield, S., Coll, R.K., Vyle, B. and Bolstad, R. (2003) Zoos as a source of free choice learning. Research in Science \& Technological Education 21(1): 67-99.

UNESCO. (n.d.) United Nations decade of education for sustainable development (20052014), http://portal.unesco.org/education/en/ev.php-

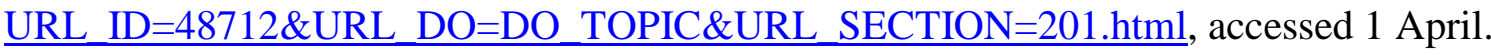


Uriely, N. (2005) The tourist experience: Conceptual developments. Annals of Tourism Research 32(1): 199-216.

Urry, J. (2002) The tourist gaze. 2nd Edition. Theory, culture \& society. London: SAGE.

Viner, D. and Nicholls, S. (2006) Climate change and its implications for international tourism. In: D. Buhalis and C. Costa (eds.) Tourism management dynamics: trends, management and tools. Oxford: Butterworth Heinemann.

WCED. (1987) Our common future. Oxford: World Commission on Environment and Development.

WTO. (2003) Climate change and tourism: Proceedings of the 1st international conference on climate change and tourism. Djerba, Tunisia, 9-11 April 2003.

Yin, R.K. (2009) Case study research, design and methods. Forth Edition. Applied social research methods series. Thousand Oaks, CA: Sage.

Zeppel, H. (2008) Education and conservation benefits of marine wildlife tours: Developing free-choice learning experiences. The Journal of Environmental Education 39(3): 3-17.

Zografos, C. and Allcroft, D. (2007) The environmental values of potential ecotourists: A segmentation study. Journal of Sustainable Tourism 15(1): 44-66. 